\title{
ASAS KETERBUKAAN DALAM PELAKSANAAN FUNGSI LEGISLASI DEWAN PERWAKILAN RAKYAT (Perspektif Islam dan Hukum Positif di Indonesia)
}

\author{
Sirajul Munir \\ Institut Agama Islam Negeri Kudus \\ Email : sirajulmunir@iainkudus.ac.id
}

\begin{abstract}
Laws have binding power and coercion after being passed in the legislative process. Therefore, the legislative process is bound by several principles, one of which is the principle of openness. Openness is the principle of governance that is based on participation. This article aims to explain the principle of openness in the implementation of the legislative function of the House of Representatives (DPR) in terms of Islamic Law and Positive Law in Indonesia. The type of method used in writing this article is normative juridical using a qualitative approach based on the statute approach and the conceptual approach. Sources of data are used in the form of secondary data which includes primary legal materials, secondary legal materials, and tertiary legal materials. For data analysis, this article uses a qualitative descriptive data analysis technique. The results of the study indicate that the principle of openness in the implementation of the legislative function of the DPR was formed to accommodate public participation so that the legislative product does not harm the community. In Islam, several arguments can be used as a normative basis for comparing shura and the principle of openness in the implementation of the legislative functions of the DPR. The principle of openness has the same meaning as Shura in the legislative process, namely public involvement. Shura in Islamic teachings provides a moral foundation when the DPR carries out its legislative function in a democratic system.
\end{abstract}

Keywords: Principle of openness, Legislative Function, House of Representatives

\begin{abstract}
Abstrak
Undang-undang memiliki daya ikat dan daya paksa setelah disahkan dalam proses legislasi. Oleh sebab itu, proses legislasi terikat pada beberapa asas, salahsatunyaadalahasasketerbukaan.Keterbukaanmerupakanasaspenyelenggara anpemerintahan yang bertumpupadapartisipasi.Tulisan artikel ini bertujuan untuk menjelaskan tentang asas keterbukaan dalam pelaksanaan fungsi legislasi Dewan Perwakilan Rakyat (DPR) ditinjau dari Hukum Islam dan Hukum Positif di Indonesia.Jenis metode yang digunakan dalam penulisan artikel ini adalah yuridis normatif dengan menggunakan basis pendekatan kualitatif yakni statute approach dan conceptual approach. Sumber data yang digunakan berupa data sekunder yang meliputi bahan hukum primer, bahan hukum sekunder, dan bahan hukum tersier. Untuk analisis data, artikel ini menggunakan teknik analisis data berupa deskriptif kualitatif. Hasil penelitian menunjukkan bahwa asas keterbukaan dalam pelaksanaan fungsi legislasi DPR dibentuk untuk mengakomodir partisipasi publik sehingga produk legislasi tidak merugikan masyarakat. Dalam Islam, ada beberapa dalil yang dapat dijadikan landasan
\end{abstract}


normatif untuk membandingkan antara syura dan asas keterbukaan dalam pelaksanaan fungsi legislasi DPR. Asas keterbukaan memiliki makna sama dengan Syura dalam proses legislasi yakni keterlibatan publik. Syura dalam ajaran Islam memberikan landasan moral ketika DPR melaksanakan fungsi legislasinya dalam sistem demokrasi.

Kata Kunci: Asas keterbukaan, Fungsi Legislasi, Dewan Perwakilan Rakyat

\section{PENDAHULUAN}

Setiap kekuasaan berpotensi mendekatkan pada kesewenanganwenangan. Oleh sebab itu, Montesquieu mengupayakan pencegahan adanya penyalahgunaan kekuasaan oleh orang-orang yang sedang berkuasa dengan cara mengatur pembagian kekuasaan pemerintahan dalamtiga bagian, yaitu kekuasaan negara dalam menghasilkan suatu aturan hukum yang menjadi domain lembaga legislatif, kekuasaan Negara untuk melaksanakan suatu aturan yang telah disusun oleh legislatif diperankan oleh lembaga eksekutif dan lembaga yudisial mengambil peran sebagai penegak aturan perundang-undangan (Budiarjo, 2002: 151).

Lembaga legislatif adalah lembaga pembentuk undang-undang dengan anggota-anggota yang merepresentasikan rakyat. Sebagai lembaga yang merepresentasikan rakyat maka fungsi legislasi sama artinya dengan menjalankan fungsi merumuskan kebijakan kepentingan seluruh rakyat (Yani, 2018: 349). Lembaga tersebut memiliki beberapa tahapan dalam menjalankan fungsi legislasinya, yaitu dimulai dari inisiatif untuk merencanakan, menyusun membahas, hingga menyetuuji suatu undang-undang. Di samping itu,lembaga legislatif juga dapat menyetujui perjanjian atau persetujuan yang sudah disepakati oleh negara Indonesia dengan negara lainserta dokumen-dokumen hukum penting lainnya (Asshiddiqie, 2009: 299).

Walaupun anggota-anggota legislatif dianggap sebagai representasi rakyat, akan tetapi dalam proses legislasi tetap memerlukan peran serta masyarakat supaya terhindar dari politik hukum yang berupaya menyelundupkan kepentingan kekuasaan (oligarki) melalui proses legislasi. Proses legislasi harus berjalan sebagai proses pembentukan kebijakan yang dapat mengakomodir kepentingan publik (Jati, 2012: 331). Partisipasi publik dalam proses legislasi merupakan wujud dari pelaksanaan salah satu asas dalam Undang-Undang Republik Indonesia Nomor 12 Tahun 2011 tentang Pembentukan Peraturan PerundangUndangan yakni asas keterbukaan.

Asas keterbukaan yang merupakan pilar utama negara demokrasi juga ditemukan dalam ajaran Islam. Dalam mekanisme pengambilan keputusan Nabi Muhammad SAW sebagai kepala pemerintahan saat itu 
mengembangkan budaya syura' terkait dengan persoalan kemasyarakatan (Munawir Sjadzali, 2008: 16). Dalam tafsir Al-Maraghi, Al-Baghawi, maupun dalam tafsir Ibnu Katsir dinyatakan bahwa musyawarah berfungsi untuk menyelesaikan masalah. Salah satu peninggalan sejarah Islam dalam praktik musyawarah adalah lahirnya Piagam Madinah sebagai konsensus sosial yang mampu mengakomodasi berbagai keyakinan dan suku di wilayah Madinah (Mubarok, 2019: 67).

Partisipasi publik harus dilaksanakan sebagai suatu proses musyawarah yang berlandaskan pada kebutuhan dan kepentingan masyarakat. Dengan demikian proses pembentukan undang-undang tidak hanya bersifat formalitas sebagai pemenuhan prosedur pembentukan undang-undang, tetapi mampu menghasilkan kebijakan yang akomodatif. Salah satu dampak buruk jika asas keterbukaan tidak diimplementasikan dengan baik maka akan berimplikasinya pada kurang terbangunnya kesadaran masyarakat dalam menerapkan hukum sehingga dapat memunculkan muncul aksi-aksi penolakan.

Sudah banyak penelitian maupun artikel yang membahas tentang asas keterbukaan dalam pembentukan perundang-undangan, antara lain artikel yang ditulis oleh Angga Prastyo, dkk. dengan judul "Pengaturan asas keterbukaan dalam pembentukan undang-undang" yang dimuat dalam Jurnal Cakrawala Hukum, Volume 11 No. 2 Agustus 2020. Jurnal Cakrawala Hukum, Volume 11 No. 2 Agustus 2020. Angga Prastyo, dkk mengulas tentang perlunya transparansi dalam proses Pembentukan Undang-Undang diawali dengan ketersedian informasi sehingga masyarakat punya kesempatan untuk memahami proses Pembentukan Undang-Undang yang sedang berlangsung dan dapat memberikan masukan (Prastyo, Wahidin, and Supriyadi 2020).

Penelitian yang dilakukan Rahendro Jati, berjudul "Partisipasi Masyarakat Dalam Proses Pembentukan undang-Undang Yang Responsi, Jurnal Rechtsvinding, Volume 1 Nomor 3, Desember 2012. Proses penciptaan undang-undang merupakan kewenangan lembaga DPR dan dibahas bersama Pemerintah memunculkan relasi dengan masyarakat sebagai pihak yang memberikan mandat pada wakilnya di parlemen tetapi juga sebagai pihak yang akan terikat pada aturan hukum pasca disahkan (Jati, 2012). Penelitian yang dilakukan Norisman Tumuhu, dengan judul "Fungsi Legislasi Dewan Perwakilan Rakyat Republik Indonesia Indonesia". Norisman Tumuhu menjelaskan, bahwa membentuk undang-undang adalah kekuasaan DPR. Namun, menurut penelitian ini,dalam menjalankan fungsi legislasi, DPR wajib berpedoman pada prinsip dan asas yang telah diatur dalam undang-undang sebagai rambu legislasi. Penting pula bagi DPR untuk memperhatikan kedalaman materi kajian Naskah Akademik yang memuat nilai-nilai luhur bangsa 
Indonesia sehingga penyusunan undang-undang sesuai dengan kehendak masyarakat dalam rangka mengatur tatanan hidup (Tumuhu 2013).

Ketiga karya ilmiah di atas, secara umum dapat dikatakan memiliki persamaan tema dengan tulisan artikel ini yaitu mengkaji asas keterbukaan dalam proses penciptaan undang-undang. Namun demikian, terdapat perbedaan dengan artikel ini yaitu penelitian ini lebih menfokuskan pada kajian tentang bagaimana asas keterbukaan dalam pelaksanaan fungsi legislasi DPR, dan bagaimana tinjauan Islam dan hukum positif terhadap asas keterbukaan dalam fungsi legislasi DPR. Sedangkan penulisan artikel ini bertujuan untuk mendiskripsikan dan menjelaskan asas keterbukaan dalam pelaksanaan fungsi legislasi DPR ditinjau dari Islam dan hukum positif di Indonesia.

\section{METODE PENELITIAN}

Jenis penelitian yang dipilih dalam penulisan artikel ini adalah yuridis normatif yakni menelaah hukum dikonsepkan sebagai peraturan tertulis yang termuat dalam peraturan perundang-undangan. Sedangkan pendekatan yang digunakan adalah pendekatan undang-undang (statute approach) yakni dengan melihat peraturan hukum tertulis yang ada khususnya yang berkaitan dengan proses legislasi yang dilakukan oleh DPR dan conseptual approach yakni dengan mengkaji konsep hukum positif dan hukum Islam yang berhubungan dengan permasalahan legislasi dan asas keterbukaan.

Sumber data yang digunakan ialah data sekunder yang meliputi: 1) bahan hukum primer berupa Undang-Undang Nomor 12 Tahun 2011 tentang Pembentukan Peraturan Perundang-Undangan, dan ayat-ayat AlQur'an dan Hadis yang masih ada relevansinya untuk mengkaji permasalahan dalam artikel ini; 2) bahan hukum sekunder berupa bukubuku, skripsi, tesis, artikel jurnal dan lain-lain; 3) bahan hukum tersier, yakni merupakan data tambahan yang didapat dari beberapa sumber yang berkaitan dengan penelitian berupa Kamus Besar Bahasa Indonesia, Kamus hukum, Ensiklopedia maupun web atau jurnal online yang berkaitan dengan penelitian ini. Selanjutnya, data yang diperoleh dianalisis menggunakan metode kualitatif dan disajikan secara diskriptif.

\section{PEMBAHASAN}

\section{Asas Keterbukaan dalam Pelaksanaan Fungsi Legislasi Dewan Perwakilan Rakyat}

Demokrasi adalah suatu pemerintahan yang dijalankan oleh rakyat dimana kekuasaan mayoritas warga negara dijalankan. Dengan demikian rakyat memiliki andil dalam setiap berjalannya suatu pemerintahan. Salah satu caraberdemokrasi adalah dijalankan melalui perwakilan. Rakyat memilih wakil-wakilnya untuk selanjutnya diutus dalam mengambil 
keputusan demi keberlangsungan hidup bangsa Indonesia. Secara yuridis sosiologis salah kekuasaan tersebut dijalankan oleh Dewan Perwakilan Rakyat (DPR) yang terbentuk dari amanat rakyat Indonesia. (Asshiddiqie, 2010: 414).

Negara Indonesia merupakan negara hukum yang tujuan dasarnya adalah mewujudkan kesejahteraan publik. Oleh sebab itu, maka dibutuhkan suatu kebijakan berupa produk legislasi yang dapat menjadi penghantar pada tujuan tersebut. Berdasarkan Pasal 20 ayat (1) UndangUndang Dasar Negara Republik Indonesia Tahun 1945 secara eksplisit memandatkan fungsi legislasi berupa kekuasaan membentuk undangundang kepada DPR. Artinya setiap penciptaan undang-undang dalam rangka mewujudkan kesejahteraan publik merupakan kewenangan DPR.

Kekuasaan pembentukan undang-undang juga dielaborasi dalam Undang-Undang Nomor 12 Tahun 2011 tentang Pembentukan Peraturan Perundang-Undangan dan Undang-Undang Nomor 17 Tahun 2014 tentang MPR, DPR, DPR, DPD, dan DPRD serta dalam Peraturan DPR tentang Tata Tertib. Fungsi legislasi tersebut dijalankan sebagai representasi suara rakyat (Rajab, 2017: 38). Fungsi representasi atau keterwakilan harus dipahami dalam pengertian bahwa para anggota DPR menyerap aspirasi rakyat lalu kemudian memperjuangkannya di lembaga legislatif. Oleh sebab itu maka setiap proses, mulai dari perencanaan, penyusunan, pembahasan, sampai pada pengesahan atau penetapan peraturan perundang-undangan harus dilakukan dengan memberikan ruang partisipasi publik yang transparan dan terbuka (asas keterbukaan) agar masyarakat dapat memberikan pandangannya terkait dengan legislasi yang sedang berlangsung baik secara lisan ataupun tertulis.

Proses legislasi yang nantinya menghasilkan suatu produk hukum dengan daya ikat secara umum maka rakyat menjadi penentu variabel pembentukannya maupun pelaksanaannya. Untuk menghasilkan suatu produk hukum yang baik maka harus didasakan pada beberapa dasar yakni sosiologis, yuridis dan filosofis. Dasar sosiologis didapat dari partisipasi publik dalam proses legislasi (Syahmardan, 2012: 144).

Tahapanproses legislasi yang dilakukan oleh lembaga perwakilan rakyat yakni sebagai berikut:

1. Perencanaan

Penyusunan program legislasi nasional merupakan langkah awal dalam rencana pembentukan undang-undang. Prolegnas disusun secara terencana, terpadu, dan sistematis antara DPR dengan Pemerintah yang dikoordinasikan oleh DPR melalui badan legislasi yang merupakan salah satu alat kelengkapan DPR. Walaupun tugas legislasi dimandatkan pada legislator tetapi dalam perencanaan yang terpadu dan sistematis tidak sekedar memperhatikan kehendak legislator saja, tetapi perlu peka terhadap problematika hukum dan 
kebutuhan hukum masyarakat yang sewaktu-waktu dapat terjadi diluar program legislasi nasional. Proses legislasi harus sejalan dengan prinsip demokrasi yang menghendaki keterlibatan seluruh stakeholder (pemangku kepentingan). Pada awal proses inilah asas keterbukaan sudah harus diterapkan.

Proses legislasi tidak hanya sekedar ingin memenuhi kepastian hukum, tetapi juga dalam rangka memberikan kemanfaatan, keadilan yang menjadi kehendak rakyat (I Gde Pantja Astawa dan Suprin Na'a, 2008: 69). Untuk memenuhi hal tersebut maka perlu pengkajianpengkajian secara ilmiah sehingga pertimbangan pertimbanganpertimbangan yang muncul tidak semata-mata politik pertimbangan yuridis, sosiologis, ekonomis, sosial, budaya, filosofis dan sebagainya (Meri Yarni, 2014: 52).

Dalam rangka meminimalisasi potensi resistensi publik dalam proses legislasi makasejak dimulainnya perencanaan pembentukan peraturan perundang-undangan yang terefleksi dalam penyusunan Program Legislasi Nasional (Prolegnas), legislator harus menjalin kerja sama dengan masyarakat untuk mendapatkan saran dan pertimbangan dari masyarakat dengan memberikan ruang partisipasi. Oleh sebab itu, maka perlu dilakukan penyebarluasan informasi melalui sosialisasi menggunakan platfrom digital yang dapat diakses dengan mudah oleh masyarakat. Keterbukaan informasi juga harus diimbangi dengan ruang partisipasi dengan maksud untuk mepermudah masyarakat dalam memberikan masukan.

Penyebarluasan dimaksudkan untuk mensosialisasikan proses legislasi supaya tersebar informasi secara luas.Hal ini dapat dilakukan dengan kunjungan kerja serta membuka diri untuk berdiskusi dalam rangka mendengar pendapat publik. Sehingga dalam proses legislasi, legislator memperoleh masukan masyarakat serta para pemangku kepentingan untuk dapat diijadikan pertimbangan. Kesan baik akan munncul dalam proses legislasi yang terbuka karena menunjukkan bahwa tidak ada maksud tersembunyi yang diselundupkan dalam proses legislasi. Walaupun ada upaya penyelundupan kepentingan untuk segelintir golongan tertentu maka dengan terbukanya informasi akan mudah dikoreksi.

2. Penyusunan

Dalam proses penyusunan atau pembahasan, RUU dipublikasikan untuk mendapat saran dan masukan guna penyempurnaan RUU. Penyusunan RUU yang diinisiasi oleh pemerintah maka terlebih dahulu dibentuk panitia antar kementerian dan/atau antar non kementerian yang beranggotakan:

a. Kementerian yang menyelenggarakan urusan pemerintahan di bidang hukum; 
b. Kementerian/lembaga pemerintah non kementerian dan/atau lembaga lain yang terkait dengan substansi yang diatur dalam RUU; dan

c. Perancang peraturan perundang-undangan yang berasal dari instansi pemrakarsa. RUU diajukan harus disertai dengan naskah akademik sebagai landasan ilmiah.Dalam tahap penyusunan inipartisipasi publik terbatas diwakili oleh ahli hukum, praktisi, atau akademisi yang menguasai permasalahan yang berkaitan dengan materi RUU yang sedang disusun dengan memperhatikan pula masukan yang mungkin ada pada tahap-tahap sebelumnya. Perwakilan disini diposisikan sebagai pemberi bantuan bagi yang kepentingannya diwakili karena tidak dapat membuat keputusan sendiri (Nina A. Kohn 2021: 316).

3. Pembahasan

Pembahasan RUU dilakukan berdasarkan 2 tingkat pembicaraan yaitu tingkat I dalam rapat komisi, rapat gabungan komisi, rapat Badan Legislasi, rapat Badan Anggaran, atau rapat panitia khusus bersama dengan menteri yang mewakili Presiden serta rapat dengar pendapat umum. Rapat Dengar Pendapat Umum (RDPU) antara alat kelengkapan DPR yang membahas rancangan undang-undang dengan masyarakat selalu dihadapkan pada kualitas representasi, karena DPR lah yang menentukan pihak-pihak yang akan diundang dan didengar pendapatnya. Sedangkan tingkat II (paripurna) dilakukan penyampaian laporan yang berisi proses, pendapat mini fraksi, pendapat mini DPD, dan hasil pembicaraan tingkat seblumnya. Partisipasi masyarakat pada tahap ini sudah tidak dilibatkan lagi dan sepenuhnya dijalankan oleh para wakil rakyat. Pada tahap ini pula akan ditentukan apakah RUU disetujui menjadi undang-undang atau tidak.

4. Pengesahan/penetapan dan pengundangan

RUU yang sudah disetujui bersama akan disampaikan ke Presiden untuk disahkan menjadi undang-undang dalam jangka waktu maksimal 7 hari sejak disetujui. Setelah itu, Presiden mengesahkan dengan membubuhkan tanda tangan dalam jangka waktu maksimal 30 hari terhitung sejak RUU disetujui bersama. Namun apabila RUU tidak ditandatangani oleh Presiden selama jangka waktu itu, secara otomatis RUU sah menjadi Undang-Undang dan wajib diundangkan. Dalam tahapan pengundangan, partisipasi publik secara langsung tidak diperlukan lagi, sebab merupakan kewenangan penuh pemerintah. Pengundangan dilakukan oleh Menteri Hukum dan Hak Asasi Manusia dengan tujuan agar setiap orang mengetahuinya yang ditempatkan dalam Lembaran Negara Republik Indonesia. 
Terdapat beberapa cara yang bisa dilakukan dalam melembagakan partisipasi publik pada proses legislasi. Pertama, penyebar luasan rancangan peraturan perundang-undangan agar diketahui publik sehingga publik dapat memberikan respon sebelum RUU disahkan; kedua,melibatkan anggota masyarakat yang memiliki keahlian (koompetensi) dalam bidang tertentu yang sedang menjadi bahasan dalam proses legislasi. Anggota tersebut bekerja secara independen berdasarkan keilmuan/keahliannya di dalam tim atau kelompok kerja dalam penyusunan peraturan perundang-undangan serta tidak boleh terpengaruh intervensi kepentingan tertentu kecuali kepentingan publik; ketiga, terbuka untuk melakukan diskusi publik baik melalui seminar, lokakarya atau bahkan mengundang pihak-pihak yang berkepentingan (stakeholder) dalam rapat-rapat penyusunan peraturan perundangundangan.

Penilaian kinerja proses legislasi DPR dapat dilihat dari sisi kuantitas legislasi yang dibuat dan kualitasnya dalam produk legislasi (Solihah \& Witianti, 2016: 292).Terdapat beberapa faktor penting yang dapat memengaruhi sebuah produk legislasi(Sarifuddin Sudding, 2014: 370).

Pertama, institusi membentuk panitia khusus untuk melakukan distribusi rancangan undang-undang keseluruh komisi dan alat kelengkapan dan kepada publik. Kedua, peran kolektif anggota dewan sebagai penentu keputusan politik dan tenaga ahli sebagai pemberi masukan yang objektif. Sebuah produk hukum harus memiliki riset dan bobot akademis yang merepresentasikan kebutuhan hukum masyarakat. Ketiga, harmonisasi hubungan antar anggota dewan dalam rangka efektivitas pembahasan suatu produk hukum. Walaupun keputusan dewan dianggap sebagai keputusan politik tetapi perdebatan yang terjadi harus didesain berdasarkan norma etis.

Ada tiga tipe karakter produk hokum yang dihasilkan dalam sebuah negara, yaitu produk hukum represif, otonom dan responsif.Teori tentang tiga tipe dasar hukum yang berlaku dalam masyarakat yaitu (Jati, 2012:336):

1. Hukum dapat diperalat oleh keuasaan sehingga membuat corak hukum menjadi represif. Hukum represif adalah hukum yang mengabdi pada kekuasaan dan ketertiban sosial yang represif, sehingga cenderung mengedepankan pemaksaan tanpa memperhatikan kepentingan rakyat. Hukum represif menimbulkan tidak terpeliharanya ketertiban sosial, kenyamanan umum, pertahanan, otoritas dan penyelesaian konflik sosial;

2. Hukum sebagai institusi otonom yang dapat melindungi integritas dirinya sehingga mampu menjinakkan represi. Adapun hukum otonom adalah hukum yang bertujuan untuk mengontrol kekuasaan yang represif. Dalam artian, hukum otonom adalah kebalikan hukum 
represif. Beberapa karakteristik yang melekat pada hukum yang otonom adalah, pertama, menekan aturan-aturan hukum sebagai langkah utama dalam mengawasi kekuasaan resmi. Kedua, adanya independensi penegak hukum yang tidak dapat diintervensi oleh kekuatan politik maupun ekonomi, serta memiliki otoritas eksklusif untuk mengadili pelanggaran hukum secara adil dan bijaksana;

3. Hukum sebagai kristalisasi kehendak yang bersumber dari aspirasi berbagai respon atas kebutuhan publik. Hukum responsif tidak hanya berorientasi pada hasil dan tujuan-tujuan yang ada didalam hukum itu sendiri tetapi juga mengakomodir nilai-nilai yang ada di luar hukum. Dalam teori hukum responsif ini, tatanan hukum dapat dinegosiasi, bukan justru dimenangkan secara subordinasi. Karakteristik hukum yang responsif mencari nilai-nilai yang tersirat dalam peraturan dan kebijakan. Hukum responsif menawarkan bukan saja procedural justice, tetapi justru berorientasi pada tegaknya keadilan dengan tetap mempertimbangkan kepentingan publik. Dengan demikian dapat dipahami bahwa hukum responsif menekankan pada substantial justice dan keadilan lebih dipahami sebagai quidius, bukan quidiuris (Jati, 2012: 336).

Proses legislasi merupakan realisasi dari politik hukum nasional yang menyusun arah, bentuk, maupun isi dari hukum yang mengakomodir keinginan dan kebutuhan rakyat (Ismayawati, 2021: 116). Keikutsertaan dalam proses legislasi merupakan salah satu bentuk partisipasi publik dalam penyelenggaraan kekuasaan negara yang diwujudkan dalam pembentukan peraturan perundang-undangan.

\section{Tinjauan Hukum Islam dan Hukum Positif Terhadap Asas Keterbukaan dalam Pelaksanaan Fungsi Legislasi Dewan Perwakilan Rakyat}

Prinsip dasar hukum Islam adalah mengatur kehidupan umat manusia yang berdimensi vertikal maupun horizontal. Dimensi vertikal menitikberatkan pada perbaikan relasi manusia dengan Allah SWT. Hukum Islam dalam dimensi ini masyhur disebut dengan "Fikih Ibadah". Sedangkan dimensi horizontal, menitikberatkan pada perbaikan relasi manusia dengan sesama manusia dan lingkungan sekitar. Sejumlah literatur keislaman mendefinisikan hukum Islam dalam dimensi ini sebagai "Fikih Muamalat". Begitu kompleks dan luasnya Islam mengorganisir gerak-gerik umat manusia. Aspek aksiologi hukum Islam ini bertolak dari tujuan agama Islam sendiriuntuk memperbaiki, menyelamatkan dan mempersatukan kehidupanmanusiasecara utuh (Ilyas, 2018: 296).

Jamak dipahami bahwa nas Al-Qur'an dan Hadis menjadi sumber rujukan para ulama dan cendikiawan muslim dalam merumuskan hukum Islam. Bahwa kemudian muncul ijmak, qias, dan seterusnya dalam 
diskursus hukum Islam, itu lebih merupakan produk kreatif para ulama ketika melakukan interpretasi terhadap nas-nas yang bersifat umum atau belum jelas (an-nusus al-mutasyabihat), dengan tetap mengacu pada dalil normatif yang ditetapkan nas. Dari sini jelas bahwa formulasi hukum Islam perpegang pada asas-asas yang memungkinkan bagi terwujudnya kemaslahatan umat manusia sebagai tujuan dasar diturunkannya syariat Islam. Tanpa asas-asas yang jelas, formulasi hukum Islam maupun positifmeminjam bahasa Satjipto Rahardjo hanya merupakan seperangkat peraturan perundang-undangan tanpa arah dan tujuan yang jelas.

Merujuk pada Ali Imron, ada enam asas hukum Islam yang juga dapat diintegrasikan ke dalam hukum nasional. Pertama, asas dar'u almafasid muqaddamun ala jalbi al-mashalih (menolak kerusakan lebih utama dari meraih maslahat). Kedua, asas fahmu al-mukallaf (pemahaman subjek hukum terhadap substansi hukum). Ketiga, asas musyawarah. Keempat, asas mendahulukan kewajiban daripada hak. Kelima, asas adam al-haraj (tidak mempersempit masalah). Keenam, asas keadilan(Imron, 2015 : 230). Keenam asas hukum Islam yang dikemukakan Ali Imron tidak bersifat opsional yang hanya dapat dipilih salah satunya saja dalam perumusan hukum. Melainkan, semua asas tersebut harus dimunculkan dalam proses perumusan hukum Islam maupun positif, agar menghasilkan produk hukum yang berkeadilan dan manusiawi. Namun, dalam konteks artikel ini keenam asas tersebut tidak dibahas secara keseluruhan. Kajian ini hanya difokuskan pada asas musyawarah yang dinilai lebih "dekat" dengan asas keterbukaan dalam proses legislasi. Asas musyawarah dalam hal ini akan dicari titik kesamaannya dengan asas keterbukaan.

Budaya musyawarah memiliki basis teologis dalam Islam. Kitab suci Al-Qur'an memperkenalkan "musyawarah" dengan istilah "syura" yang secara etimologi berarti mengambil madu dari sarang lebah. Dalam perkembanagannya, syura mengalami perluasan maksa dari sekedar mengambil madu dari sarang lebah. Ia juga diartikan sebagai suatu forum yang mewadahi pertukaran ide, pendapat, termasuk juga saran-saran yang solutif atas sebuah persoalan. Syura dalam pengertian ini nampak lebih modern, di dalamnya tersirat bentuk nation-state di mana budaya musyawarah berlangsung dalam satu forum bernama lembaga legislatif (Azhary, 1992: 23).

Dalam kitab suci Al-Qur'an dan Hadis, syura' berarti mengambil pendapat. Konsep syura' dimaksudkan untuk memecahkan masalahmasalah yang muncul dalam kehidupan berbangsa dan tatanan bernegara sehingga diperoleh kesepakatan kolektif. Syura' sendiri memiliki landasan normatif dalam kitab suci Al-Qur'an sebagai salah satu dasar hukum bagi sebuah pemerintahan.Antara lain: "dan bermusyawarahlah dengan mereka dalam urusan itu. Kemudian apabila kamu telah membulatkan tekad, maka 
bertawakallah kepada Allah. Sesungguhnya Allah menyukai orang-orang yang bertawakal kepada-Nya" (QS Ali Imran: 159).

Istilah syura' atau musyawarah berasal dari bahasa Arab, yaitu kata syura' yang mempunyai arti sesuatu yang tampak atau jelas.Adapun beberapa ayat Al-Qur'an yang akar katanya merujuk pada syura' atau musyawarah terdapat alam surat Ali Imran (3): 159. Awalnya lafaz fi alamri (فى الامر ) dimaknai bahwa ruang lingkup musyawarah di sini awalnya terbatas pada peperangan, kemudian dalam perkembangannya menjadi makna yang lebih luas pada urusan kemasyarakatan dan ketatanegaraan dengan tetap dibatasi pada wilayah hubungan sisoal, bukan persoalan ketuuhanan (ibadah mahdlah).

Sedangkan dalam surat asy-Syura (42): 38, musyawarah yang dikerjakan tidak jauh berbeda dengan makna yang terdapat pada surat Ali Imran yakni musyawarah dilakukan dalam urusan umat khususnya kaum muslimin dalam kategori kemaslahatan yang dibenarkan oleh pemerintahan yang sah dan berlaku dalam adat-istiadat serta sesuai dengan perkembangan situasi dan kondisi suatu daerah atau Negara. Persoalan agama yang sudah jelas dan ditetapkan oleh wahyu tidak lagi menjadi bagian dari musyawarah, sebab jika itu dilakukan maka persoalan agama seperti aqidah, ibadah ( $\left.t a^{\prime} a b b u d i\right)$ ditetapkan oleh hasil musyawarah maka agama ini menjadi bergeser menjadi aturan manusia bukan aturan tuhan (Abdullah, 2016: 320).

Dapat kita pahami bahwa ayat-ayat yang berhubungan dengan musyawarah ini menunjukkan adanya pesan akan pentingnya musyawarah dalam kehidupan tak terkecuali dalam urusanlegislasi. Kata syura' juga berasal dari akar kata kerja (fi'il) "syawara-yusyairumusyawaratan", yang artinya menjelaskan, menyatakan atau mengajukan, dan mengambil sesuatu. Dengan demikian musyawarah dan pelaksanaan asas keterbukaan memiliki dasar yang normatif dalam Al-Qur'an maupun sunah, tetapi pelaksanaannya dalam konteks kehidupan umat Islam dan ketatanegaraan mengalami bentuk dan corak yang variatif. Hal itu berarti bahwa musyawarah merupakan sesuatu yang niscaya dilakukan dalam menyelesaikan setiap persoalan kehidupan umat manusia, karena syuramemiliki pengaruh yang sangat besar, terutama dalam mengaturketatanegaraan yang diwujudkan dalam produk hukum hasil legislasi.

Nabi Muhammad SAW sangat menghayati ajaran Islam tentang musyawarah. Dalam kapasitasnya sebagai pemimpin agama maupun negara, Nabi SAW tidak saja mengajarkan tetapi juga mempraktikkan secara langsung budaya musyawarah di hadapan kepada umatnya. Bukti riil bahwa Nabi sangat memandang penting musyawarah dalam penyelenggaraan urusan publik, adalah disepakatinya Piagam Madinah. Piagam Madinah yang merupakan sebuah konstitusi Negara Madinah 
digagas oleh Nabi SAW dengan kesepakatan bersama antara kaum Nasrani, Muslim dan Yahudi (Zamhari, 2004: 13). Tujuannya jelas, untuk menyatukan kaum atau kelompok (agama) yang berbeda-beda dalam satu konsensus kenegaraan. Tentu dapat dibayangkan, bagaimana mungkin sebuah kesepakatan kelompok berbeda akan diperoleh jika tidak ditempuh melalui proses musyawarah.

Konsep musyawarah senantiasa menarik dan mengandung banyak sisi relevansi dengan ketatanegaraan, setidaknya dari sisi mekanisme pengambilan keputusan mengenai penyelenggaraan urusan publik. Sebagai kepala pemerintahan, Nabi SAW mengembangkan pola yang cukup variatif, termasuk dalam mengembangkan budaya syura' (musyawarah; negosiasi) dikalangan para sahabatnya. Status kerasulan tidak mengurangi semangat Nabi SAW untuk berunding dengan para sahabat terkait persoalan-persoalan ummat. Akan tetapi ternyata Nabi SAW tidak sekedar menggunakan satu pola saja. Kadang Kala Nabi meminta masukan dengan para sahabat yang memiliki usia lebih tua dari pada Nabi atau dengan orang-orang yang dipandangnya ahli dalam bidang tertentu. Nabi juga tak jarang mempercayakan publik untuk mengatasi masalah-masalah umum, khususnya masalah yangberdampak luas kepada masyakarat.

Setiap kebijakan publik membutuhkan keterlibatan publik dengan pertimbangan yang ketat dan memiliki dampak yang bernilai baik. Pemimpin yang baik menurut Islam adalah pemimpin yang mampu menerapkan budaya musyawarah dalam memutuskan suatu perkara serius. Konsep syura' telah dipraktikkan langsung oleh Nabi SAW sehingga menjadi sebuah ajaran yang tak dapat ditolak. Adapun bentuk penerapan syura'ini, antara lain, ketika terjadi perselisihan kaum Quraisy yang ingin memindahkan hajar aswad di tubuh ka'bah. Menyadari hal itu, Nabi SAW menawarkan solusi yang mampu mewadahi hak dan memberi kepuasankepada Bani tanpa harus merugikan pihak-pihak lain yang terlibat. Kebijaksaan ini dihasilkan melalui musyawarah dan oleh karena itu menjadi ajaran yang patut diikuti oleh para sahabat dan generasi penerus selanjutnya (Imran, 2015: 130).

Musyawarah merupakan upaya konkrit untuk memadukan berbagai argumentasi yang terdiri dari banyak aspirasi dalam satu kesepakatan bersama. Umumnya, proses musyawarah diakhiri dengan permufakatan bersama. Walaupun kepentingan masyarakat luas merupakan hal terpenting dari pada kepentingan mayoritas terakdang proses musyawarah tidak selalu menemukan kebulatan pendapat. Pada tahap inilah maka prosedur manajemen partisipatif didasari oleh mayoritas suara.

Lembaga legislatif sebagai representasi syura' dan selaras dengan perkembangan demokrasi di zaman modern ini,khususnya di Indonesia, 
masih saja menjadi bahan "perbincangan" di kalangan pemikir Islam. Perbincangan yang dimaksud terkait dengan apakah sistem demokrasi Barat sejalan dengan Islam atau tidak, apakah majelis syura' sama dengan parlemen dalam sistem demokrasi barat, dan apakah keanggotaan majelis syura' ditentukan oleh partai politik atau oleh rakyat secara langsung. Perbincangan yang memicu perdebatan tersebut muncul karena memang Al-Qur'an tidak menjelaskan secara tegas pengaturan majelis syura' (legislatif), bagaimana proses pembentukannya, dan apa saja fungsi dan tugasnya.

Berdasarkan uraian di atas, maka menurut penulis bahwa Islam mempunyai perhatian terhadap pentingnya budaya musyawarah. Selain sebagai bentuk perintah Allah SWT, musyawarah juga dimaksudkan untuk mewujudkan sebuah tatanan masyarakat yang demokratis dan tidak otoriter. Dengan diberdayakannya budaya musyawarah, setiap orang yangbermusyawarah akanterlatih untuk mengemukakan pendapatnya dalam sebuah forum dengan baik, sehingga diperoleh hasil atau solusi yang solutif dan dapat menyelesaikan masalah yang sedang terjadi. Sejauh ini, budaya musyawarah terlihat jelas dalam proses legislasi dengan asas keterbukaannya.

Dikalangan pemikir muslim modern, terdapat tiga varian utama arus pemikiran ketatanegaraan, yaitu; arus formalistik, simbiotik, dan sekularistik. Demikian halnya dengan pendapat Munawir Sjadzali, bahwa relasi pemikiran ketatanegaraan dan agama meliputirelasi tradisional, moderat dan sekuler. Kelompok pertama menerima sistem syura' dan tidak menyamakannya dengan demokrasi. Kelompok kedua mendukung sistem syura' dan menyelaraskannya dengan demokrasi di era modern. Dan kelompok ketiga menolak secara total sistem syura', dengan pernyataan cukup keras bahwa Islam tidak pernah menentukan ajaran tentang sistem politik tertentu. Di luar itu semua, belakangan banyak muncul pemikir muslim modern yang mengemukakan bahwa syura' dan demokrasi bukan saja sejalan, tetapi justru sama persis. Keduanya memiliki kesamaan yang terletak pada penolakannya terhadap individulisme dan kesewenang-wenangan. Sebagaimana dalam syura' demokrasi terdapat sistem perwakilan rakyat yang dalam konteks Indonesia disebut lembaga legislatif (Santoso, 2013: 58).

Relasi Islam dan kekuasaan negara dapat melahirkan sikap, perilaku politik dan budaya politik yang berorientasi pada nilai-nilai yang Islami. Relasi ini muncul tidak lepas dari sifat alamiah kekuasaan yang memunculkan keprihatinan moral budaya politik. Pada akhirnya dapat ditegaskan kembali bahwa agama dan negara merupakan dua institusi yang memiliki pengaruh kuat dalam kehidupan bernegara.

Keberadaan negara memberi "ruang" bagi keberlangsungan agama. Agama Islam dengan nilai-nilai universalnya yakni konsep syura dapat 
memberi rambu-rambu kepada negara dalam mengatur urusan publik. Keterpaduan antara keduanya turut mewujudkan kemaslahatan publik di satu sisi, dan "baldatun tayyibatun wa robbun ghafur" di sisi yang lain. (Ahmad A. Sofyan dan M. Roychan Madjid, 2003: 12).

Keberadaan Asas keterbukaan yang terdapat dalam UndangUndang Nomor 12 Tahun 2011 yakni agar masyarakat dapat kesempatan seluas-luasnya untuk berpartisipasi pada setiap tahapan pembuatan peraturan perundang-undangan. Mengingat pentingnya partisipasi masyarakat, maka masyarakat tidak sekedar hanya dijadikan sebagai sumber dukungan dalam kontestasi pemilu dan menjadi sasaran kebijakan. Masyarakat harus diposisikan sebagai pemilik peran dalam pembuatan kebijakan publik utamanya dalam proses legislasi sebab pada akhirnya hasil legislasi akan kembali juga pada masyarakat (Muhaimin and Wahab 2019: 45). Hal tersebut tentu sesuai dengan nilai-nilai universalajaran Islam dalam hal ini konsep syura. Dalam membuka ruang musyawarah dan meningkatkan partisipasi aktif masyarakat dalam pembentukan peraturan perundang-undangan maka setidaknya perlu disediakan akses yang mudah dijangkau masyarakat dengan kebenaran informasi yang dapat dipertanggung jawabkan (Asyari 2018).

Serap aspirasi dapat terwujud jika peranstruktural mampu menyediakan akses informasi yang jelas terhadap rancangan undangundang yang akan masuk dalam program legislasi baik secara pasif maupun aktif. Dalam hal ini, menurut penulis, pemerintah sudah seharusnya melakukan penyebarluasan informasi terkait RUU kepada masyarakat melalui media cetak, media elektronik, dan/atau media lainnya.Informasi yang dapat diakses keberadaannya harus jelas.Jangan sampai terjadi kasus beredarnya naskah yang beragam sebagaimana terjadi pada RUU Cipta Kerja yang menujukkan tidak adanya kejelasan informasi.

Akses informasi dan kejelasan informasi berpengaruh pada pemetaan kelompok orang yang mempunyai kepentingan atas substansi Rancangan Peraturan Perundang-Undangan sehingga partisipasi dalam mempengaruhi keputusan (public participation indecision making) dapat lebih terarah. Dengan demikian maka gagasan dari lapisan masyarakat kemudian dapat dipelajari dan digkaji sebagai pertimbangan dalam merumuskan undang-undang. Penyelenggaraan musyawarah dalam rangka menyerap aspirasi harus dilakukan secara jujur dan akuntabel. Musyawarah dilaksanakan tanpa adanya rekayasa yang menunjukkan seolah-olah konstituen aktif terlibat dalam musyawarah tetapi pada kenyataannya musyawarah hanya sekedar dilaksanakan dalam rangka memenuhi prosedur adminitratif dan melewatkan hal yang substantif. Hal ini berarti bahwa asas keterbukaan juga harus bersifat transparan 
terhadap setiap tahapan mulai dari tahapan perencanaan, penyusunan, pembahasan, pengesahan atau penetapan, hingga pengundangan.

Penyusunan daftar Rancangan Undang-Undang salah satunya didasarkan pada kebutuhan hukum masyarakat yang diaspirasikan hal tersebut menunjukkan pentingnnya aspirasi publik dalam proses legislasi. Oleh sebab itulah maka DPR bertugas untuk menyerap, menghimpun, menampung, dan menindaklanjuti aspirasi masyarakat (Pasal 7g Peraturan Dewan Perwakilan Rakyat Republik Indonesia Nomor 1 Tahun 2020 Tentang Tata Tertib). Bahkan tugas tersebut dapat dianggap sebagai suatu kewajiban yang komitmennya diikrarkan dalam sumpah DPR untuk memperjuangkan aspirasi rakyat yang diwakili untuk mewujudkan tujuan nasional demi kepentingan bangsa dan Negara Kesatuan Republik Indonesia.

\section{SIMPULAN}

Berdasarkan pembahasan di atas, dapat disimpulkan bahwa asas keterbukaan dalampelaksanaan fungsi legslasi DPR dibentuk untuk mengakomodir partisipasi publik sehingga produk legislasi tidak merugikan masyarakat. Dalam Islam, ada beberapa dalil yang dapat dijadikan landasan normatif untuk membandingkan antara syura dan asas keterbukaan dalam pelaksanaan fungsi legislasi DPR. Asas keterbukaan memiliki makna sama dengan Syura dalam proses legislasi yakni keterlibatan publik. Syura dalam ajaran Islam memberikan landasan moral ketika DPR melaksanakan fungsi legslasinya dalam sistem demokrasi.

\section{DAFTAR PUSTAKA}

\section{Buku-buku}

Ahmad A. Sofyan dan M. Roychan Madjid. (2003). Gagasan Cak Nur Tentang Negara dan Islam. Yogyakarta: Titian Press.

Asshiddiqie, J. (2009). Pengantar Ilmu Hukum Tata Negara. Jakarta: PT. Rajagrafindo Persada.

Asshiddiqie, J. (2010). engantar Ilmu Hukum Tata Negara. Jakarta: Raja Grafindo Persada.

Budiarjo, M. (2002). Dasar-Dasar Ilmu Politik. Jakarta: PT. Gramedia Pustaka.

I Gde Pantja Astawa dan Suprin Na'a. (2008). Dinamika Hukum dan Ilmu Perundang- Undangan di Indonesia. Bandung: Alumni.

Ilyas, H. (2018). Prinsip-Prinsip Teologis Islam Rahmatan Lil 'Alamin. Jakarta: PT. Pustaka Alvabet.

Imron, A. (2015). Membumikan asas hukum islam di indonesia. Semarang.

Zamhari, Muhammad Hari. 2004. Agama Dan Negara: Analisis Kritis Pemikiran Nurcholish Majid. Jakarta: Raja Grafindo Persada. 


\section{Jurnal-jurnal}

Asyari, Hasyim. 2018. "Asas Keterbukaan dalam Pembentukan Peraturan Daerah (Study Kasus Di Kabupaten Lombok Tengah)." Refleksi Hukum: Jurnal Ilmu Hukum 2 (1): 81-96. https:/ / doi.org/10.24246/jrh.2017.v2.i1.p81-96.

Azhary, M. Thahir. 1992. Negara Hukum. Jakarta: Bulan Bintang.

Budiarjo, Miriam. 2002. Dasar-Dasar Ilmu Politik. Jakarta: PT. Gramedia Pustaka.

I Gde Pantja Astawa dan Suprin Na'a. 2008. Dinamika Hukum Dan Ilmu Perundang- Undangan di Indonesia. Bandung: Alumni.

Ilyas, Hamim. 2018. Prinsip-Prinsip Teologis Islam Rahmatan Lil 'Alamin. Jakarta: PT. Pustaka Alvabet.

Imron, Ali. 2015. Membumikan Asas Hukum Islam Di Indonesia. Semarang. Ismayawati, Any. 2021. "Pendekatan dan politik hukumdalam pembangunan hukum pidana di indonesia." Yudisia : jurnal pemikiran hukum dan hukum islam 12: 109-26.

Jati, Rahendro. 2012. "Partisipasi Masyarakat Dalam Proses Pembentukan Undang-Undang Yang Responsif." Jurnal Rechts Vinding: Media Pembinaan Hukum Nasional 1 (3): 329. https:// doi.org/10.33331/rechtsvinding.v1i3.88.

Meri Yarni. 2014. “Tidak Sedikit Perda," 155-72.

Mubarok, Ahmad Agis. 2019. "Musyawarah Dalam Perspektif Al-Qur'an." MAGHZA: Jurnal Ilmu Al-Qur'an Dan Tafsir 4 (2): 147-60. https://doi.org/10.24090/maghza.v4i2.3550.

Muhaimin, Muhaimin, and Abd Wahab. 2019. "Santri, Misi Politik Dan Perumusan Kebijakan Publik Di Kabupaten Jember." YUDISIA: Jurnal Pemikiran Hukum Dan Hukum Islam 10 (2): 157. https://doi.org/10.21043/yudisia.v10i2.6228.

Munawir Sjadzali. 2008. Islam Dan Tata Negara; Ajaran, Sejarah, Dan Pemikiran. Jakarta: UI Press.

Nina A. Kohn. 2021. "Legislating Supported Decision-Making." Harvard Journal on Legislation 58 (2).

Prastyo, Angga, Samsul Wahidin, and Supriyadi Supriyadi. 2020. "Pengaturan Asas Keterbukaan Dalam Pembentukan UndangUndang." Jurnal Cakrawala Hukum 11 (2): 125-35. https://doi.org/10.26905/idjch.v11i2.4136.

Rajab, Achmadudin. 2017. "Peran Penting Badan Keahlian Dpr Ri Dalam Sistem Hukum Pembentukan Peraturan Perundang-Undangan Yang Mendukung ( Important Role of the Expertise of the Parliament of the Republic of Indonesia in the Legal System Formation of Regulation of the Invitation T." Journal Legislasi Indonesia 14: 233-44.

Santoso, Lukman. 2013. "Prinsip Syura Dalam Konstitusinal Islam." As- 
Salam 11 (3): 43-64.

Sarifuddin Sudding. 2014. Perselingkuhan Hukum Dan Politik Dalam Negara Demokrasi. Yogyakarta: Rangkang Education.

Solihah, Ratnia, and Siti Witianti. 2016. "Pelaksanaan Fungsi Legislasi

Dewan Perwakilan Rakyat Pasca Pemilu 2014: Permasalahan Dan Upaya Mengatasinya." CosmoGov 2 (2): 291. https:/ / doi.org/10.24198/cosmogov.v2i2.10010.

Syahmardan. 2012. "Pertisipasi Masyarakat: Wujud Transparansi Pembentukan Peraturan Perundang-Undangan Yang Demokratis." Legislasi Indonesia 9 (1): 135-50. jurnal.peraturan.go.id/index.php/jli/article/download/381/262.

Tumuhu, Norisman. 2013. "Fungsi Legislasi Dewan Perwakilan Rakyat Republik Indonesia Indonesia (Dpr-Ri)." Administratum, Lex 1 (2): 195-202.

Yani, Ahmad. 2018. “Analisis Kontruksi Struktural Dan Kewenangan DPR Dalam Fungsi Legislasi Berdasarkan Undang-Undang Dasar 1945." Jurnal Konstitusi 15 (2): 348. https:/ / doi.org/10.31078/jk1526.

\section{Peraturan perundang-undangan}

Undang-Undang Republik Indonesia Nomor 12 Tahun 2011 tentang Pembentukan Peraturan Perundang-Undangan

Peraturan Dewan Perwakilan Rakyat Republik Indonesia Nomor 1 Tahun 2020tentang Tata Tertib 
Sirajul Munir

Halaman ini sengaja dikosongkan 